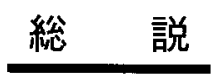

\title{
単分子膜における構造観察と䌚和現象
}

\author{
加藤 貞二 \\ 宇都宮大学工学部応用化学科 \\ （₹321-8585＼cjkstart栃木県宇都宮市陽東 7-1-2）
}

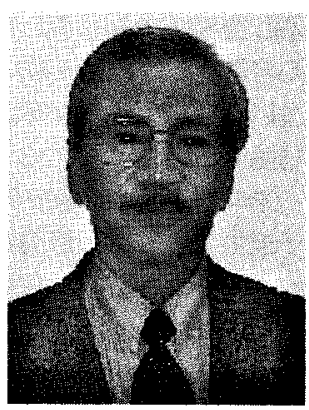

\section{Morphological Changes and Relaxations in Monolayers}

\author{
Teiji KaTo \\ Department of Applied Chemistry, Faculty of Engineering, Utsunomiya University \\ (7-1-2, Yoto, Utsunomiya-shi, Tochigi-ken 321-8585)
}

\begin{abstract}
Direct evidence has been presented for condensed phase formation in adsorbed monolayers at surfactant solution surfaces, which is quite the same as phase transitions from expanded to condensed phases in spread monolayers by compression. It thus follows that there is no clear boundary between adsorbed and spread monolayers.

However, there are many different modes of relaxation in spread monolayers ouing to the greater non-equilibrium nature of spread monolayers during compression compared to adsorbed monolayers.
\end{abstract}

Key words : Gibbs monolayers, Langmuir monolayers, spread monolayers, phase transitions, Brewster angle microscopy, relaxations, non-equilibrium nature, growing shape, equilibrium shape,

\section{1 単分子膜系}

単分子膜系として扱える代表的な系は大きく分けて， 液体表面における不溶性単分子膜（展開単分子膜），可 溶性単分子膜 (吸着単分子膜), および固体表面におけ る自己組織化単分子膜の 3 種類が考えられる。自己組織 化単分子膜については紙数の関係で省略し，ここでは不 溶性単分子膜を中心として吸着単分子膜との関係をまず 述べたい。

上で液体表面と書いたが，実際には水表面または水溶 液表面，あるいは水および水に混じらない有機液体との 界面であり, 単分子膜が関与する表面, 界面の一方は常 に水であることは重要である。な拉，この小論中では， 不溶性単分子膜と展開単分子膜を同義語として用い, 使 い分ける。

\section{2 吸着単分子膜と展開単分子膜}

界面活性化合物の水溶液の表面には自発的にその化合 物の吸着単分子膜が形成され，その表面に扰ける膜分子 の平衡吸着濃度はGibbsの取り扱いによって, 表面張
力のパルク濃度依存性のデータから実験的に求められ る。このような取り扱いによる吸着単分子膜の研究は古 くから盛んに行われており，多くの論文が報告されてき た。また，新たに形成された表面に対する界面活性分子 の吸着の動的な過程に関する研究も多数報告されてい る)。しかし，吸着単分子膜の吸着の過程においては活

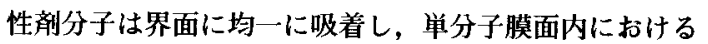
不均一構造を形成することはない，ということが研究者 間の暗黙の了解であった。ところが最近, 膜の吸着の過 程で，界面における膜分子の二次元浱度がある踣界値を 越すと単分子膜が相転移を起こし, 吸着単分子膜中に膨 張相と凝縮相が共存する直接的な証拠がいくつか報告さ れ始めた。最初の報告は Brewster Angle Microscope (BAM) の装置開発者でもあるフランスのJ. Meunier のグループによるパルミチン酸ナトリウム塩の吸着単分 子膜に関する論文である22。この水溶液の表面をサク ションポンプで吸引して既に形成されていた吸着単分子 膜を取り除き，その後清浄表面に吸着されてくる単分子 膜を BAM で観察すると，渦巻きのような特異な構造の 凝縮相のドメインが形成されることを報告している。し 
かし彼らは同時に，この凝縮相の形成は界面活性物質中 の溶解度の低い不純物，この場合はナトリウム塩になつ ていない遊離パルミチン酸の優先的吸着に原因があると 結論している。

不純物を含まない，高純度の界面活性物質の吸着単分 子膜中での凝縮相形成を報告したのはD．Vollhardtの グループが最初である゙๋。彼らは N-dodecyl-r-hydroxybutyric acid amide (DHBAA) の濃度 $2.0 \times 10^{-5} \mathrm{M}$ の溶 液表面をバリヤーで掃き，既に形成されていた吸着単分 子膜を取り除いたあとの表面に対する吸着過程を，表面 圧の時間変化と BAM による表面観察の同時測定で追跡

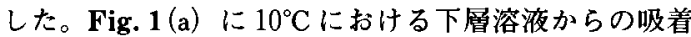
による表面压上昇過程を示す。時刻 1000 秒より少し前

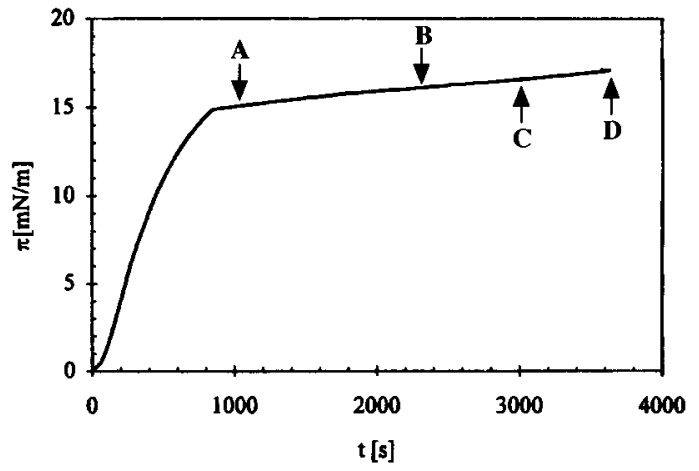

(a)

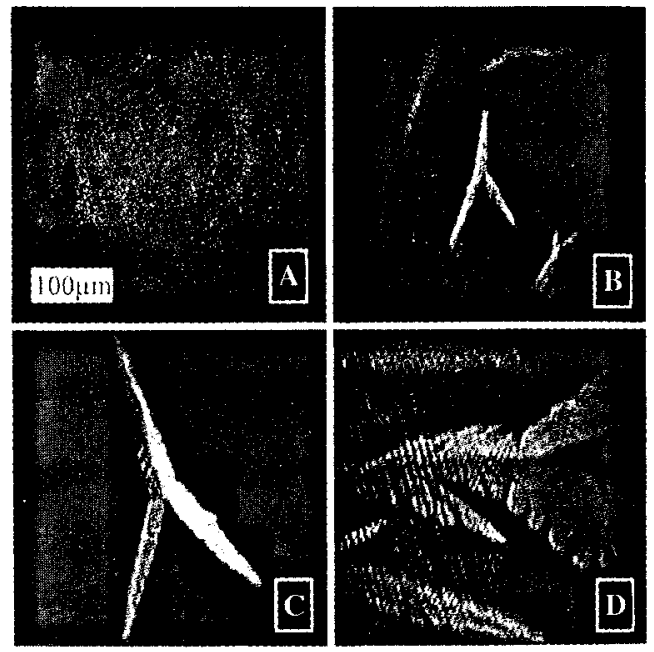

(b)

Fig. 1(a) $\pi$-t isotherm of $\mathrm{N}$-dodecyl- $\gamma$-hydroxybutiric acid amide aqueous solution of $2 \times 10^{-5} \mathrm{M}$ at $10^{\circ} \mathrm{C}$.

(b) BAM images at the points A, B, C and D on the $\pi$-t isotherm in Fig.1(a).
で表面圧一時間曲線（ $\pi^{-} \mathrm{t}$ 等温線）に折れ曲がりを生じ， その後はわずかな傾きをもつ水平線になる。 $\pi$ - $\mathrm{t}$ 等温線 上のポイント (A)，(B)，(C)，(D) で観察した BAM 像を Fig. 1 (b)，(A) 一 (D) に示す。（B）点から羽毛の ようなデンドリックな二次元結晶相が観察され始め, 時 間とともに成長してゆくのが分かる。 $\pi^{-} \mathrm{t}$ 等温線は (A) 点で折れ曲がっているにもかかわらず，(B) 点まで凝 縮相構造が観察されない理由としては，結唱核が小さく て BAMの解像度では見えないか，核発生頻度が小さく て，たまたま観察領域に見えなかったのであろう，と説 明している。

吸着膜中に凝樎相ドメインが形成される系の $\pi-\mathrm{t}$ 等温 線としては, Fig. 1(a) は央は特殊な例であることを次 の図で示そう4)。Fig. 2 (a) に，筆者らの測定した 2-hydroxyethyl laurate（2-HEL）の水溶液における $\pi^{-} \mathbf{t}$ 等温線のバルク濃度依存性を示す。一番低い濃度の例を 除いてどの濃度においても cusp point が現れ，そのあと に plateau 領域が続いている。cusp point が現れる表面 圧はバルク濃度に依存せず一定である。しかし cusp pointにいたるまでの時間は, バルク濃度が高いほど短い。

注目すべきは濃度の高い場合の等温線の plateau 領域 の後である。たとえば一番濃度の高い $2 \times 10^{-5} \mathrm{M}$ の場合 (曲線 V)，約 300 秒で cusp point が現れ， $20 \mathrm{mN} / \mathrm{m} の$ 表面压で plateau 領域が続くが，1000 秒近くなるとふた たび表面圧が上昇しはじめ，長時間かかって約 43

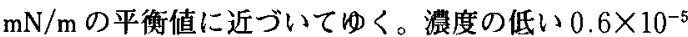
$\mathrm{M}$ の場合（曲線 I）は，いくら長時間待っても $\pi^{-} \mathrm{t}$ 等 温線に cusp pointは現れず，BAMでも凝縮相の形成が 観察できない。この図の $1.0 \times 10^{-5} \mathrm{M}$ に相当するのが Fig. 1 (a) であり，BAMにより凝䑿相ドメインの形成

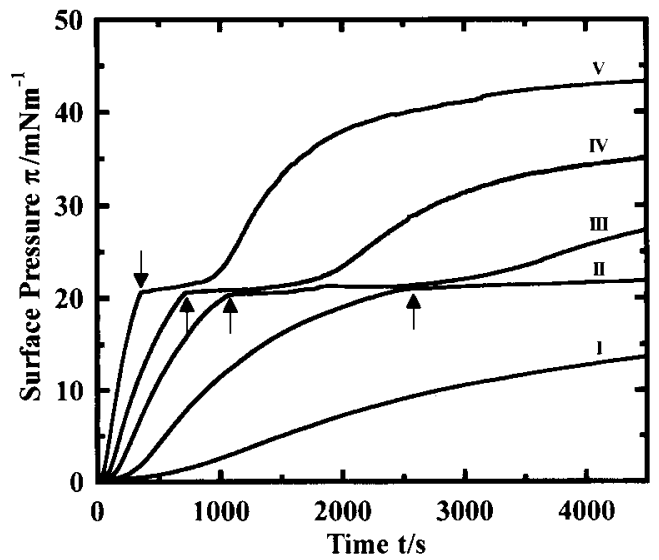

Fig. 2(a) Bulk concentration dependency of $\pi-t$ isotherms of 2-hydroxyethyl laurate (2-HEL) aqueous solutions at $5^{\circ} \mathrm{C}$. I : $0.6 \times 10^{-5} \mathrm{M}$, II : $1.0 \times 10^{-5} \mathrm{M}$, III : $1.4 \times$ $10^{-5} \mathrm{M}, \mathrm{IV}: 1.8 \times 10^{-5} \mathrm{M}, \mathrm{V}: 2.0 \times 10^{-5} \mathrm{M}$ 
が観察できるが, plateau 領域後の表面圧がほとんど上 昇しない特別な濃度である。Fig. 2 (b) に, 濃度 $1.4 \times$ $10^{-5} \mathrm{M}$ の場合（曲線血）の, cusp point を過ぎてからの BAM イメージを示す。B点で 1500 秒, D 点で 2000 秒, $\mathrm{F}$ 点で 2600 秒， $\mathrm{G}$ 点で 4200 秒に打ける観察である。 Vollhardt らの観察同样, cusp pointを越えてしばらく は凝縮相形成が見えないが，B点から円形の凝縮相ドメ インが見え始める。この時点でのドメインサイズは小さ いもので直径 $20 \mu \mathrm{m}$ ，大きいものが $80 \mu \mathrm{m}$ 程度であり， 時間とともに成長してゆく。C点でのイメージに一番明 瞭に钼察されるが，全体に明るく見えるドメインと暗い ドメインがある。BAM 像のコントラストは膜の厚さの
違いでもつくが, 主として屈折率の異方性で現れる。屈 折率の異方性は結局分子の傾きの方向の違いである。C 点のイメージにおけるドメインの明暗は，ドメイン全体 として P 偏光面内に分子が傾いているドメインは暗く みえ，それに直交した方向に分子が傾いているドメイン は明るくみえるためと考えられる。しかしDのイメー ジになると，ドメインのなかにさらにストライプ構造が 見えてくる。このストライプの数が増えてゆく形式でド メインの大きさが成長していることが分かる。ドメイン の中で分子がどのように配列してストライプ構造ができ ているかは, 現在ポツダムの Max-Planck 研究所と共同 研究で, SOR 光を用いた単分子膜の X 線回折実験が進
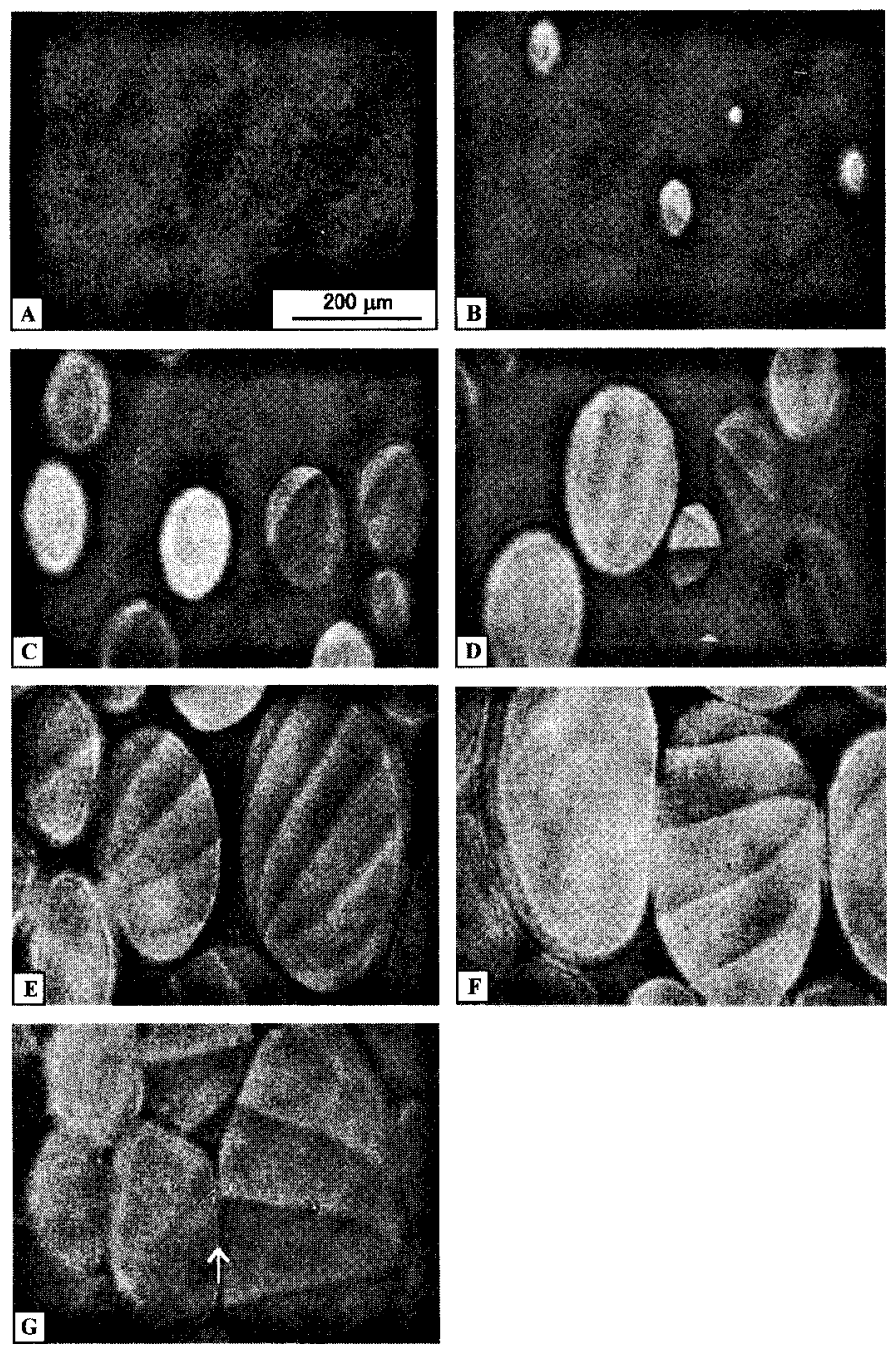

Fig. 2(b) BAM images of $1.4 \times 10^{-5} \mathrm{M}$ aqueous solution of 2-HEL after the cusp point on $\pi-t$ isotherm(III) $\mathrm{A}(1000 \mathrm{~s}) ; \mathrm{B}(1500 \mathrm{~s}) ; \mathrm{C}(1700 \mathrm{~s}) ; \mathrm{D}(2000 \mathrm{~s}) ; \mathrm{E}(2600 \mathrm{~s}) ; \mathrm{F}(3300 \mathrm{~s}) ; \mathrm{G}(4200 \mathrm{~s})$ 
行中であり, いずれ報告できると思うが, ドメイン構造 の詳練について記述することはここの目的ではないので 省略する。

ここで強調しておきたいのは，plateau領域を過ぎて 表面圧が再び上昇を始め，長時間後に一定圧に到達した 時点が, 系の真の熱力学的平衡状態である，ということ である。そこでは表面全体が単一凝縮相の単分子膜で覆 われている。 $\pi^{-\mathbf{t}}$ 等温線に cusp point が現れ凝縮相ドメ インができ始め，等温線の plateau 領域で膨張相 (Fig. 1(b) あるいはFig. 2(b) における BAM イメージで， 凝縮相ドメインを囲む暗い部分）と凝縮相の二相が共存
する状態は，熱力学的平衡状態ではない。むしろ，バル クからの吸着により増加しつつある活性㓲分子の表面浱 度がある臨界值に達したために，熱力学的理由というよ りは, 動力学的理由で凝縮相ドメインの形成が促進され た結果と考えるべきであろう。

D. Vollhardt らは, $\mathrm{N}$-( $\gamma$-hydroxypropyl)-tridecanoic acid amid (HTRAA) 水溶液のバルクから表面への吸着 過程を理論的に解析し，表面吸着濃度の時間変化を計算 $し て, \pi^{-} \mathrm{t}$ 等温線から $\pi^{-} \mathrm{A}(\mathrm{t})$ 等温線に変換するシミュ レーションを行っだ)。Fig. 3(a) にHTRAAの $4^{\circ} \mathrm{C}$ と $10^{\circ} \mathrm{C}$ に抢引る害測の $\pi-\mathrm{A}$ 等温線（図中の細い曲線）と，

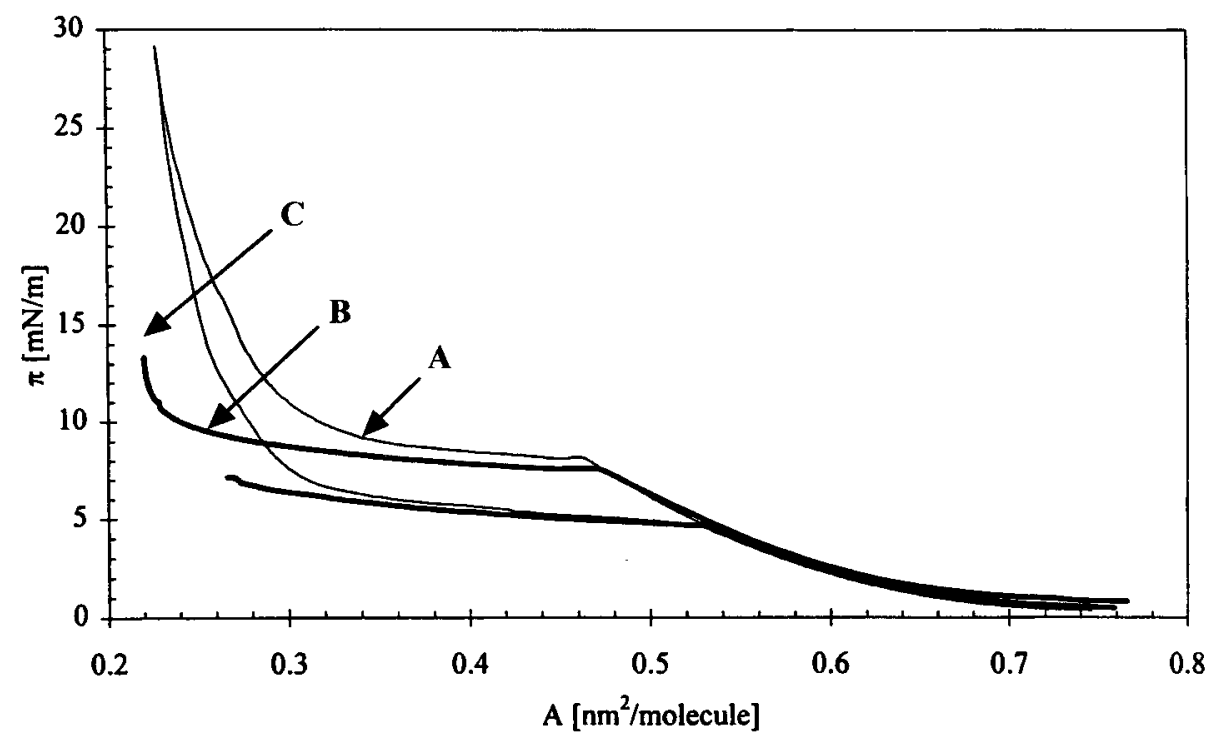

(a)
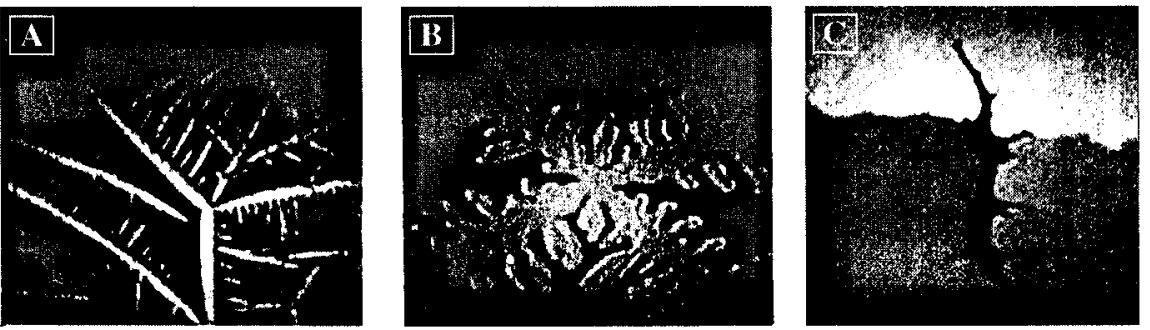

(b)

Fig. 3(a) $\pi$-A isotherms of spread monolayers of HTRAA at $4^{\circ} \mathrm{C}$ and $10^{\circ} \mathrm{C}$ (observed, thin solid lines), and calculated $\pi$-A isotherms of HTRAA from the $\pi$-t isotherms at the same temperatures (thick solid lines).

(b) (A) A BAM image of the HTRAA spread monolayer (just after the phase transition) (B) A BAM image of the HTRAA adsorbed monolayer (just after the phase transition) (C) A BAM image of the HTRAA adsorbed monolayer near the final equilibrium. 
$\pi-\mathrm{t}$ 等温線からシミュレーションによって変換された $\pi-\mathrm{A}$ 等温線（図中の太い曲線）を示す。両者を比較す ると, 相転移開始までのいわゆる液体膨張膜領域と相転 移圧は，非常に良い一致を示していることが分かる。相 転移の終了域近くで両者にズレが見られるが，相転移終 了近くから再び表面圧が上昇する傾向も再現されてい る。

この図で注目すべきは圧縮で形成される凝縮相と, 自 己吸着によって形成される凝縮相のモルフォロジーの違 いである。同じ $10 \mathrm{mN} / \mathrm{m}$ の表面圧における BAM 像を Fig. 3(b) に示す。圧縮によって形成された凝縮相は先 端の非常に鋭いデンドリックな形態をしている（A）。 一方，吸着によって形成された凝縮相もデンドリックで はあるが，幅が広く先端がかなり丸みを帯びていること が分かる (B)。同図 (C) に, 吸着が大局的平衡に近づ いた状態での BAM 像を示すが，凝縮相のデンドリック な形態はほとんど消失し，非常に大きな均一なドメイン の集合として, 溶液表面全面が凝縮相で覆われている。 BAM 像における均一な明るさの領域は，その中では膜 分子が規則正しく均一に配向, 配列していることを意味 するので, 吸着によって形成される凝縮相は, 圧縮によっ て形成される凝縮相よりかなり大きな巨視的領域で規則 正しい分子配列構造をとれる，ということができる。こ れは，圧縮による凝縮相形成の非平衡性が，吸着による 凝縮相形成に比べて非常に大きいことを意味する。

ところで吸着過程において, ある臨界膜分子密度に達 すると動力学的に凝縮相が形成されるが, この過程の膨 張相と凝縮相の 2 相共存は熱力学的に許されたものでは なく, 大局的平衡は液表面が凝縮相のみの 1 相で覆われ た状態であることを前に述べた。この大局的平衡におけ る表面圧は, 溶液濃度や温度に依存するが, 相転移を起 こす臨界表面圧より $10 \mathrm{mN} / \mathrm{m}$ 程度高く, 温度上昇とと もに相転移圧との差は小さくなる。

前項で $\pi-\mathrm{t}$ 等温線と $\pi-\mathrm{A}$ 等温線の同一性を述べた。 $\pi-\mathrm{t}$ 等温線における大局的平衡表面圧の存在から帰納す れば，圧縮によって相転移を起こす展開単分子膜にも， 相転移表面圧より少し上に，そこまでは膜が熱力学的に 安定に存在できる平衡圧が存在するであろうことが推論 できる。不溶性単分子膜におけるこの平衡圧の存在は, アントワープ大学の P. Joosによって主張されたことが あるが，筆者はこの論文を見つけられなかった。この平 衡圧は温度に依存するが, この表面圧より高い圧で存在 する単分子膜は非平衡状態にあり，本質的に不安定であ る。

いわゆる固体膜とよばれる領域は外圧（バリヤーによ る圧縮）によって強制的にもたらされた，熱力学的には まったく非平衡な状態であって，たとえば前述の吸着の ように自発的に起こる過程ではこのように高度に凝縮し
た状態は実現されない。言い方を変えれば，いわゆる固 体膜の状態は本来的に不安定な非平衡状態で，いずれは 3 次元構造を形成して崩壊してゆく。しかしだからと いって固体膜の領域では，たとえばLB膜を累積するこ とができないという訳ではない。まさに時間の問題で, 固体膜のその表面圧において，3 次元構造形成による面 積緩和の緩和時間の程度の時間内では, 固体膜の状態で の累積を継続できる。しかしこの時間をすぎれば，単分 子膜は部分的崩壊を始め, 単分子膜ではなくなる。この 緩和時間は，固体膜における制御表面圧が高いほど指数 関数的に短くなる。典型的な不溶性単分子膜形成物質で ある長鎖脂肪酸の系列では，アラキジン酸程度の鎖長が 固体膜で存在できる時間が最も長く, それより鎖長が長 くなると 3 次元結晶が安定になるためかえって固体膜崩 壊による緩和時間が短くなり，膜は逆に不安定になる。 長鎖脂肪酸と多価の金属イオンとの塩を形成させると, 固体膜状態でも準安定に存在できる時間が飛躍的に長く なる。しかしこの状態も本質的には非平衡な状態である ことを忘れてはならない。

\section{3 圧縮による相転移の領域における非平衡性}

オレイン酸（cis-9-octadecenoic acid）およびゴンド

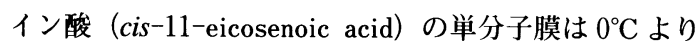
上の温度では膨張膜しか形成しないことは良く知られて いる。しかしさらに鎖長の長いエルカ酸 ( $c i s-13-$ docosenoic acid) の単分子膜は, $3^{\circ} \mathrm{C}$ から $18^{\circ} \mathrm{C}$ の温度 範囲で, 圧縮により膨張相から凝縮相への相転移を示す。 Fig. $4(\mathrm{a})$ に $\mathrm{pH} 3$ の下層水上の $\pi-\mathrm{A}$ 等温線の温度依存 性を示す。 $10^{\circ} \mathrm{C}$ では, 転移圧約 $8 \mathrm{mN} / \mathrm{m}$ で膨張相から 凝縮相への一次相転移が現れているが，ここで何が起 こっているか BAM で観察してみよう ${ }^{6}$ 。圧縮中の BAM 像を Fig. 4(b) に示す。相転移開始後のイメージ (A) で, デンドリックな 2 次元結晶の核が見え始め, 圧縮と ともに雪の結晶のような二次元結晶が成長してゆくのが 分かる。実はこの一連の BAM イメージでは，(D) ま では圧縮をしてデンドリックな凝縮相の成長をみている が，ここで圧縮を止め，(E）以降は凝縮相ドメインの 時間変化を観察している。すると，圧縮中は鋭い先端を 有して成長していた 2 次元のデンドリック結晶が放置時 間とともに太くなり，先端が丸みを帯び，約 1 時間後に はほぼ円形の凝縮相ドメインに構造緩和する（I）。し かもその円形ドメインの中が 6 個のセクターに分割され ており，七クター中では膜分子が均一な配向，配列をし ている。さらに鎖長の長いネルボン酸 (cis-15-tetracosenoic acid) でも, $18^{\circ} \mathrm{C}$ から $33^{\circ} \mathrm{C}$ の温度範囲で圧縮 により相転移を起こし, 花弁 6 枚の花のようなデンド リックな凝縮相ドメインを形成する。このような実験事 実は，相転移中に圧縮によって成長する凝縮相が，場合 


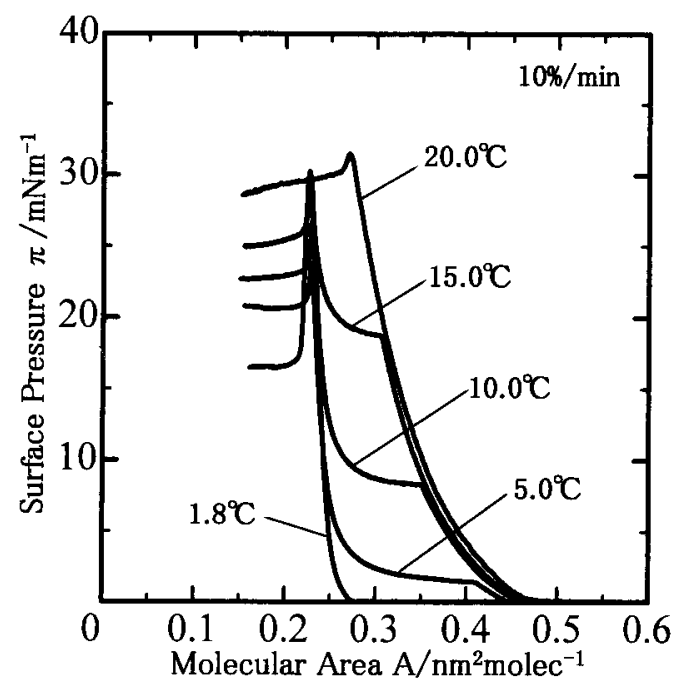

Fig. 4(a) Temperature-dependency of $\pi$ - $\mathrm{A}$ isotherms of erucic acid spread monolayers.
によっては熱力学的平衡形ではなく成長形をとることを 示している。すなわち，デンドリックドメインが成長形 であり，円形ドメインが平衡形である。エル力酸分子は 3 次元結晶中では $\omega$ 鎖も $\Delta$ 鎖もともに all-trans zigzag 構造をとっていることが, 結晶のX 線回折測定結果に より確認されている。したがって 2 次元結晶中でも分子 は“く”の字に折れ曲がった構造 (bent shape) をとる と考えることは妥当であろう。膨張相中では Gauche 眍 座を多く含む乱れた配列をとっていた分子が，凝樎相に bent shape で取り込まれる際には，接近する分子の方向 性が問題になる。また一度凝縮相に bent shapeで組み 込まれた分子は，凝縮相の表面（2次元では凝縮ドメ1 ンの周辺の線上）を簡単には動けない。この 2 つの理由 で，エルカ酸単分子膜が圧縮により相転移を起こしたと き，凝縮相を囲む膨張相における過飽和度が上がり，ま た凝縮ドメインに取り込まれた分子のドメイン周辺線上 における拡散速度が著しく抑制される。これが，エルカ 酸単分子膜において，凝縮相が平衡形をとらず成長形と

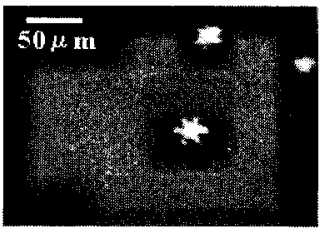

(A)

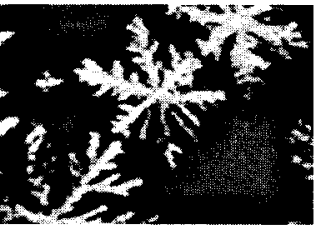

(D)

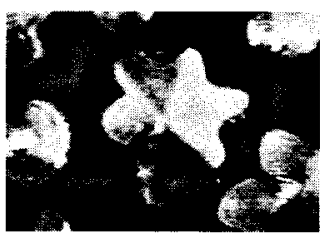

(G)

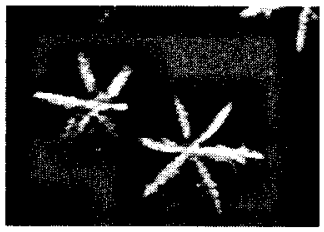

(B)

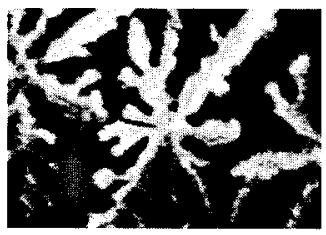

(E)

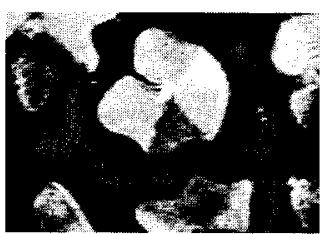

(H)

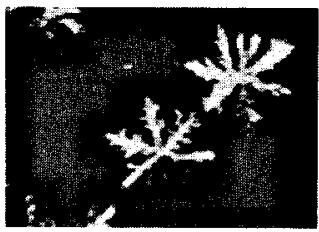

(C)

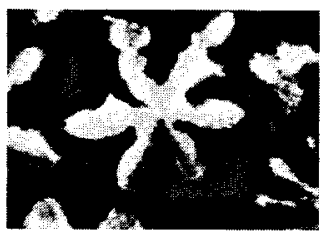

(F)

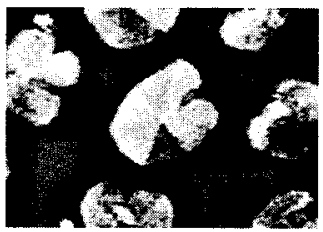

(I)

Fig. 4(b) BAM images showing morphology change of condensed phase domains in an erucic acid spread monolayer by compression at $10^{\circ} \mathrm{C}$ $(A \sim D)$ and the time course change of the condensed domains after stop compression $(D \sim I)$. (the time necessary for the change of $D \sim I$ is about 1 hour) 
して，デンドリックに成長する理由である。通常の飽和 直鎖状分子の単分子膜の多くに扎ては，かなり早い速 度で圧縮しても，円形の平衡形凝縮相ドメインが観察さ れる。

平衡形ではなく成長形をとって凝縮相ドメインが成長 する例は，他にもいくつか報告されている(7),8)。1つは N-dodecyl-L-gluconamide の展開単分子膜で, Fig. 3(b) と同じく，羽毛のような典型的なデンドリック凝縮相の 成長を示している7 。.このどちらの物質も凝縮相におけ る規則正しい分子配列に，膜分子の親水基間に形成され る複数の水素結合が関与しており，圧縮による膨張相か ら凝縮相への膜分子の取り込みに，分子の接近の方向性 が問題になることと，凝縮相に組み込まれた分子は水素 結合により顕著に動きが抑制されることが，膨張相にお ける過飽和度を高め，また組み込まれた分子の拡散を抑 制し，デンドリックな凝縮相の成長を促進している。

Fig. 3(b) の物質では，展開単分子膜よりも平衡に近い はずの吸着単分子膜においてさえ，デンドリックな凝縮 相ドメイン形成が観察されており，この2つの効果が非 常に強いことが理解される。

もう1つの例はありふれたリン脂質である dimyristoyl-phosphatidyl-ethanolamine (DMPEA) の展 開単分子膜である ${ }^{8}$ 。Fig. 5 にDMPEA 単分子膜の圧縮 による相転移における，凝縮相ドメインのモルフォロ ジ一に対する圧縮速度の効果を示す。彼らは圧縮速度を 100 倍変えており，一番速い压縮では 1 分以下で，一番 遅い压縮では 2 時問位で $\pi-\mathrm{A}$ 等温線が測定できる圧縮 速度範囲である。遅い圧縮では全体に丸みを帯びた平衡 形の凝縮相ドメインが見られるのに対し，速い圧縮では 典型的なデンドリックドメインの形成がみられる。この 物質でも親水基間の水素結合があるだけではなく，二本 のアルキル基を有するため, 凝縮相への分子の取り込み に接近分子の方向性が問題となる。このように，特別な 構造の膜物質でなくとも，展開単分子膜のかなり速い圧 縮では，顕著に非平衡性が現れる。

Fig. 6(a) に，2-hydroxyethyl laurate の展開単分子膜 の $5^{\circ} \mathrm{C}$ における $\pi$ - $\mathrm{A}$ 等温線の，観测時間依存性を示す。 この物質はFig. 2 における吸着単分子膜の研究で使用 したものと同じであるから，溶解度は非常に低いが可溶 性であり，観測時間が長いと部分的溶解による圧力緩和 で，等温線の傾きが系統的に小さくなることが明睹にみ える。装置の都合で $\pi-\mathrm{A}$ 等温線の最後までは記録され ていないが，観測時間の短い等温線には相転移の開始が

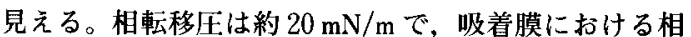
転移压と一致する゙!。相転移領域の展開単分子膜の BAM 像を Fig. 6(b) に示す。非常に小さな多数の円形 の凝縮相ドメインが観察されるが，ドメインが小さいだ けでなく内部のストライプ構造も発達していない。転移
圧はほとんど同じでありながら，吸着膜における凝縮相 構造と展開圧縮膜における凝縮相構造のこの大きな違い の原因は, 強制的に圧縮された膜における高い過飽和性, すなわち非平衡性にある。圧樎されて相転移圧に達した ときの凝縮相の核発生頻度が，展開膜の方が圧倒的に大 きいため，多数のドメインが一音に発生, 成長するので, 吸着膜における凝縮相ドメインのように，少数の核から 平衡的に成長して高度な構造を形成することができな い。

ところで，単分子膜が一次相転移を起こすと二相が共 存し，表面圧は相転移終了まで一定になるはずである。 ところが，Fig.4(a) が典型例であるが，実際にはほと んど全ての場合相転移終了まで表面圧が一定には保たれ ず，特に相転移後半で表面圧が上昇し始める。この理由 については様々な説があり，未だ決着がついていない。 たとえばJ.N. Israelachvili は，単分子膜の中に2 次元 のミセル (hemi-micelle) があり，このミセルを形成す る分子数が数十の程度の有限な数だと，相転移後半の転 移庄上昇が理論的に説明できる，と報告している ${ }^{99}{ }^{10}$ 。
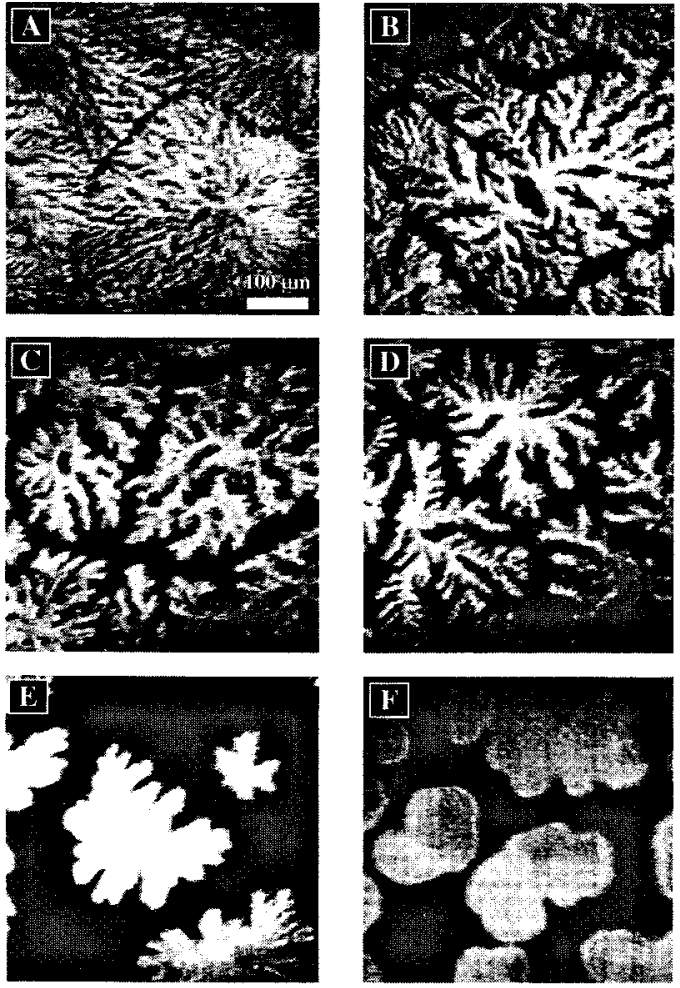

Fig. 5 Compression speed dependency of dimyristoylphosphatidyl-ethnolamine(DMPEA) spread monolayers at $10^{\circ} \mathrm{C}$. Compression speed : (A) 0.25 , (B) 0.10 , (C) 0.05 , (D) 0.025 , (E) 0.0075 , (F) $0.0025 \mathrm{~nm}^{2}$ molec. ${ }^{-1} \mathrm{~min}^{-1}$ 


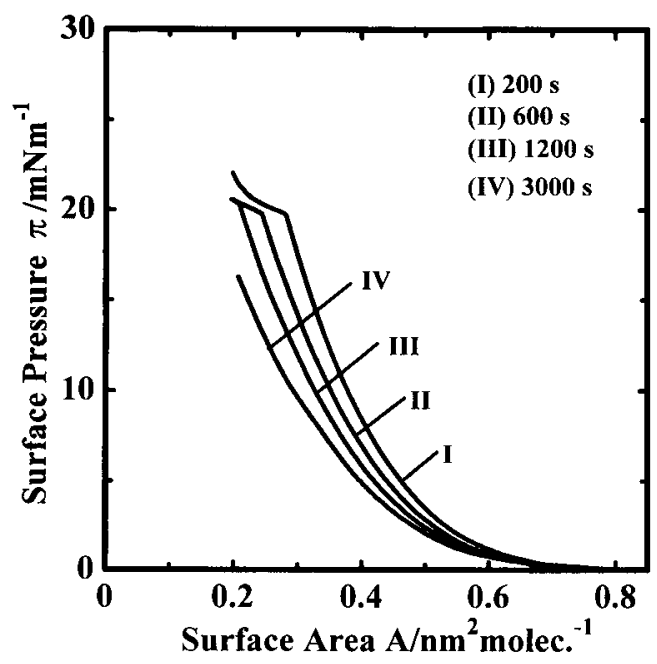

Fig. 6(a) Dependency of $\pi$-A isotherms of 2-hydroxyethyl laurate (2-HEL) spread monolayers on the time of observation $\left(\mathrm{t}_{\mathrm{ob}}\right)$ at $5^{\circ} \mathrm{C}$.

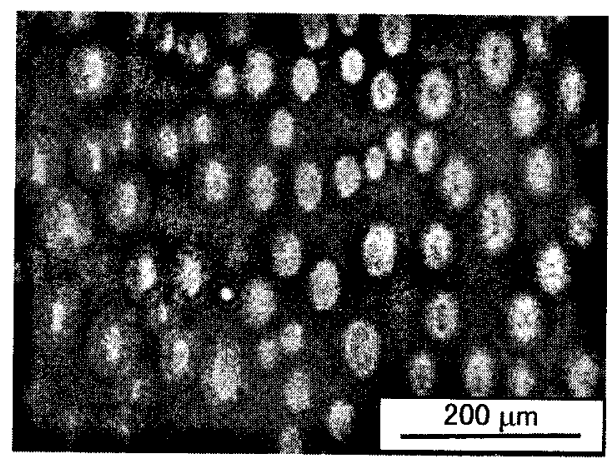

Fig. 6(b) A BAM image of a spread monolayer of 2HEL during the phase transition by compression.
しかし，単分子膜における 2 次元ミセルの存在は Langmuir 以来たびたび主張されているが，まだ一度も実験 的に証明されたことがない。

筆者は, この压上昇を, 膨張相から凝縮相への分子取 り込みによる圧緩和の楥和時間が，相転移後半において 顕著に長くなる結果であると解釈している。その1つの 証拠を Fig.7，(A)〜（C）に示す。膜物質はペンタデカ ン酸で，単純な親水基の 1 本鎖の物質であるから分子取 り込みの方向性も, 取り込まれた分子の拡散の遅れも問 題にならない。したがって，圧縮により形成される凝縮 相ドメインは単純な円形である（A）。ところが相転移 後半になると, 円形ドメインの周辺に“ヒゲ”が生え始 めるのを BAMで観察することができる（B）。膜をシ リコン基板上に移行し原子間力顕微鏡 (AFM) で観察 すると, 円形ドメインの周辺から典型的なデンドリック 凝縮構造が成長しているのを見ることができる（C）。 なぜこのような単純な物質でも相転移後半に凝縮相への 取り込みが遅机るのかは，以下のように説明することが できる。膨張相から凝縮相への膜分子の取り込みは，凝 縮相ドメインの周辺を通しておこなわれる。相転移も半 ばを過ぎると成長した凝縮相ドメインが接触，融合をは じめ, 膨張相と凝縮相の境目になっている凝縮相ドメイ ンの周辺の延べ長さが急速に減少し始める。相転移で膨 張相から凝縮相に取り込まれる分子はこの境界線を通し て移動するので, 境界線が短くなることによって, 压縮 速度に対して取り込みが間に合わなくなる。その結果， 残っている膨張相における過飽和度が急激に上昇し，デ ンドリックな成長が始まるのであろう。このことが同時 に相転移プロセスの緩和時間を長くし，表面圧の上昇に つながる。

\section{$4 \pi-\mathrm{A}$ 等温線の物理的意味}

不溶性単分子膜の最も基本的な物性として測定される のが $\pi-\mathrm{A}$ 等温線である。 $\pi-\mathrm{A}$ 等温線は $\mathrm{p}-\mathrm{V}$ 等温線の二
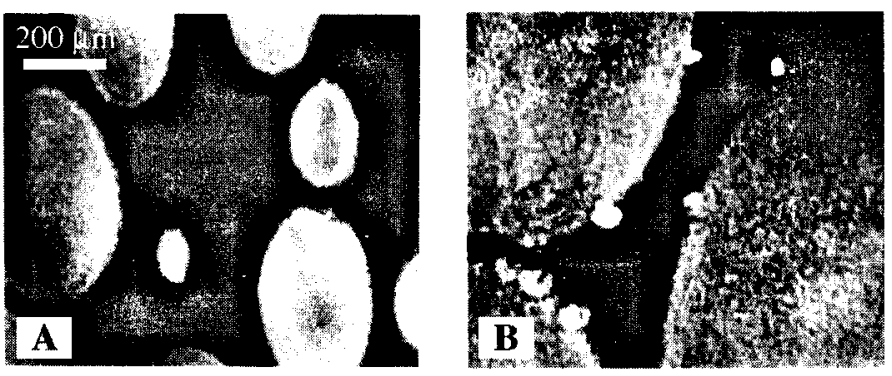

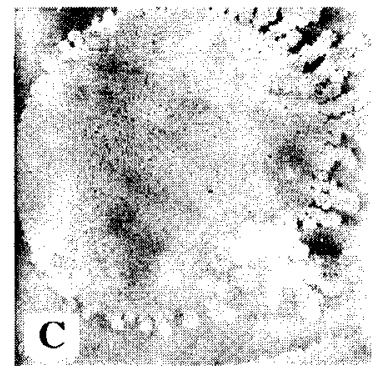

$100 \times 100 \mu \mathrm{m}^{2}$

Fig. 7 BAM images of a spread monolayer of pentadecanoic acid at $20^{\circ} \mathrm{C}$. (A) at the early stage of the phase transition, (B) at the latter stage of the phase transition, (C)an AFM image of the condensed phase domain at the latter stage of the phase transition.(See text.) 
次元版と考えられたこともある。しかし $\mathrm{p}-\mathrm{V}$ 等温線と 違い, $\pi-\mathrm{A}$ 等温線の形は影著に圧縮速度に依存する。 特に凝縮した固体膜が関係する等温線への圧縮速度の影 響が大きい。この測定の物理的意味については, 1993 年に出版された「超薄分子組織膜の科学」という本に詳 しく述べた ${ }^{11)}$ 。しかしの本がすでに絶版になっており, 参照するのが困難であるので, 関連する部分を要約して ここに再録しておきたい。

$\pi-\mathrm{A}$ 等温線はその傾きから, 表面圧縮率あるいは面 積弾性率という, 単分子膜の重要な力学的物性を求める ことができる。力学物性が測定速度 (時間) に依存する 物体は粘弹性体である。すなわち，単分子膜は粘弾性体 として扱った方が良い。 $\pi-\mathrm{A}$ 等温線は熱力学的測定と いうよりは, 力学測定の一種と考えるべきである。粘弾 性体の力学物性測定には「観測時間」の概念が必要であ る。

$\pi-\mathrm{A}$ 等温線測定の観測時間は, 圧縮の歪み速度の逆 数で与えられる ${ }^{12)}$ 。したがって $\pi-\mathrm{A}$ 等温線測定中, 観 測時間を一定に保とうと思ったら, 単分子膜を歪み速度 一定で圧縮しなければならない。このことは, 膜を压縮 するバリヤーの速度が指数関数にしたがって遅くなるこ とを意味する。通常行われる等速圧縮では圧縮の進行と ともに観測時間が短くなり，観測時間を一定に保てない。 それはともかく, $\pi-\mathrm{A}$ 等温線の形は観測時間と, 圧縮 中に単分子膜の中で起こる各種分子過程による圧低下の 緩和時間との相対的関係で決定される。压低下の緩和時 間が観測時間よりはるかに短ければ，圧縮にもかかわら ず圧は上昇しない。通常「気体膜」と呼ばれている領域 がこれに相当する。一方「固体膜」のように分子密度が 高く, 高度に凝縮している膜では分子の易動性が極度に 抑えられる結果, 緩和時間が非常に長くなり, 少しの圧 縮で表面圧が急上昇する。液体膨張膜までは通常の圧縮 速度に関係する観測時間より緩和時間が短いので, $\pi-\mathrm{A}$ 等温線の形の圧縮速度依存性はあまり顕著にはならな い。

前節までに, 単分子膜の中で起こる様々な緩和現象を 説明してきた。膜物質の下層水への僅かな溶解性も, Fig. 6 (a) に示すように顕著な緩和を引き起こす重要な 要因の 1 つである。これらの様々な緩和現象の緩和時間 と観測時間との相対的な関係で, $\pi-\mathrm{A}$ 等温線の形が決 まる。

\section{5 おわりに}

この特集号の企画として，第 2 章のタイトルは「機能 性コロイド次元分子集合体の構造と物性」であった。筆 者の担当する最初の節「単分子膜」は特に「不溶性単分 子膜」に内容が指定されていた訳ではないが, 次が「LB 膜」であることを考えれば，編集委員会の意図はこの節
で, 不溶性単分子膜の構造と物性を中心に解説すること を望んでいたのであろう。しかし筆者は, 不溶性単分子 膜と吸着単分子膜との関係から記述を始めた。

吸着過程中に一次相転移を起こすような吸着単分子膜 は, 圧縮によって相転移を起こす展開単分子膜と同等で ある。すなわちここで強調しておきたいのは, 吸着単分 子膜と不溶性単分子膜との間には明確な境界は存在しな い, ということである。そして, 不溶性単分子膜でも圧 縮により相転移を起こすような膜では, 相転移圧より少 し高いところに, ここまでは膜が熱力学的に安定に存在 できる, という圧が存在し, これより高い表面圧の単分 子膜は本質的に不安定状態にある。いわゆる固体膜とよ ばれる状態はまさにこれにあたる。

不溶性単分子膜は相転移圧より少し高い圧までは熱力 学的に安定に存在できると書いたが, それより低い圧で も圧縮により様々な非平衡状態に陥る多くの膜系があ る。 $\pi-\mathrm{A}$ 等温線の形は, 圧縮に伴う観測時間と圧縮に より単分子膜系に起こる様々な分子過程による緩和時間 との兼ね合いで決まる動的なものである。したがって逆 に, $\pi-\mathrm{A}$ 等温線の観測時間依存性あるいは圧縮速度依 存性から, 膜中で起こっている様々な緩和過程を推定す ることができる。BAM で観察できれば緩和の内容は一 目暸然である。

展開単分子膜が安定か不安定か, どの程度安定かを知 りたかったらぜひ, 圧縮速度を通常の 10 分の 1 程度に 小さくして $\pi-\mathrm{A}$ 等温線を測定してみてほしい。多くの ことが判るはずである。

最近, 超高感度化された機器の適用や, 新しい原理に よる装置の適用により, 単分子膜の構造と物性に関する 新しい情報が得られる様になってきた。ブルースター角 顕微鏡（BAM）がその代表例であるが, 他にも放射光 を用いた水面上の単分子膜の X 線回折実験 (GIXD) や, 単分子膜の二次非線形光発生 (SHG) の測定, あるい はSum Frequency Generation (SFG) 法の単分子膜へ の適用などがある。赤外線吸収スペクトル（FT-IR） についても, Photo-Elastic Modulator（PEM）を用い， $\mathrm{P}$ 偏光測定と $\mathrm{S}$ 偏光測定を高速で繰り返し, この $2 つ$ のデータを組み合わせることにより, FT-IR 測定で最 も強く妨害になる水分子の信号をキャンセルすることに よって, 水面上の単分子膜の IR スペクトルを, 高い $\mathrm{S} / \mathrm{N}$ で in situに測定することが可能になった。これら の先端的な機器について, あるいはそれらの水面上の単 分子膜への適用結果については, 紙数の関係で別の機会 にゆずりたい。

最初に記述したが, ほとんど全ての単分子膜は水系で 研究されているにもかかわらず, 単分子膜系における親 水基と水との関係をあからさまに研究している論文を筆 者は知らない。しかし圧縮により相転移を起こし, 凝縮 
して分子間距離が非常に近くなれば，親水基に配位して いる水和水も当然影響を受けるはずであり，この水和水 の取り込みあるいは押し出しもまた，膜の緩和現象に関 与しているはずである。この観点からの単分子膜の研究 については, 今後の進展を待ちたい。

なお最近，自己組織化単分子膜を含む単分子膜系にお ける膜構造形成のダイナミクスに関する小論を別に書い た。興味ある方はご参照頂きたい ${ }^{13)}$ 。

(受付： 2000 年 5 月 15 日, 受理 : 2000 年 6 月 12 日)

\section{文献}

1) S.S. Dukhin, G. Kretzschmar, R. Miller, "Dynamics of Adsorption at Liquid Interfaces", Elsevier Science (1995). D. Vollhardt, Advances in Colloid Sci., (in press).

2) S. Riviere, S. Henon, J. Meunier, Physical Review, 49, 1375 (1994).

3) V. Melzer, D. Vollhardt, Phys. Review Lett., 76,
3770 (1996).

4) Md. M. Hossain, et al., Colloids and Surfaces A, 171, 105 (2000), Langmuir, 16, 3345 (2000).

5) V. Melzer, D. Vollhardt, G. Brezesinski, H. Mohwald, J. Chem. Phys. B, 591 (1998).

6) T. Kato, Y. Yamauchi, K. Iimura, M. Suzuki, J. Colloid Interface Sci. (submitted).

7) D. Vollhardt; T. Gutberlet, G. Emrich, J.H. Fuhrhop, Langmuir, 11, 2661 (1995).

8) G. Weidmann, D. Vollhardt, Thin Solid Films, 264, 94 (1995).

9) J.N. Israelachvili, Langmuir, 10, 3774 (1994).

10) K.S. Birdi, "Lipid and Biopolymer Monolayers at Liquid Interfaces", Plenum Press, New York (1989), Section 4.7.1.

11）福田清成, 加藤貞二, 中原弘雄, 柴崎芳夫, 「超薄 分子組織膜の科学」一単分子膜から LB 膜へ一, 講談社 サイエンティフィク (1993).

12) T .Kato, Langmuir, 6, 870 (1990), 7, 2208 (1991).

13) 加藤貞二, 表面科学, 21 (10), (in press). 
[総説]

\title{
フッ素系表面改質剤
}

\author{
好野則夫 · 近藤行成 \\ 東京理科大学工学部工業化学科 \\ （テ162-8601 東京都新宿区神楽坂 1-3） \\ 東京理科大学界面科学研究所 \\ （テ162-8601 東京都新宿区神楽坂 1-3）
}

メトキシ基，エトキシ基，またはイソシアナト基を有するフッ素系シランカップリング棛の合成ならびにこれ らのシランカップリング剂を用いたガラスおよび歯科関連材料（牛歯）の表面改質について解説した。

メトキシ型シランカップリング殽はフッ素系オレフィンをヒドロシリル化したのち, ナトリウムメトキシドと 反応させることにより合成した。一方, イソシアナト型シランカップリング剤はベンゼン溶媒中, クロロ型シラ ンカップリング剂とシアン酸銀との反応により得た。これらのシランカップリング剤で改質されたガラスは高い 撥水・撥油性を示し, 中でも 3 官能性のメトキシ型およびイソシアナト型シランカップリング剂で改質されたガ ラス表面は優れた耐酸性，耐酸化性を有することが分かった。さらに，in vivo および in vitro 実験により，イソ シアナト型カップリング剂で改質された牛歯片にはプラークがほとんど付着しないことが明らかになった。この ことから，フッ素系カップリング剤が口腔の健康維持にも有用な表面改質剤であることが示唆された。

（連絡者：好野則夫） Vol.49, No.10, 1081 (2000)

\section{[総説］＼cjkstart単分子膜における構造観察と緩和現象}

\author{
加 藤 貞二 \\ 宇都宮大学工学部応用化学科 \\ （321-8585 栃木県宇都宮市陽東 7-1-2)
}

単分子膜のなかで, 不溶性単分子膜と吸着単分子膜はまったく別のものであるかのように, それぞれ別の研究 者グループによって研究されてきた長い歴史がある。ところが最近, 不溶性単分子膜が圧縮によって相転移を起 こし凝縮相を形成するように, 吸着単分子膜にも吸着の過程で凝縮相を形成する直接的な証拠が報告され始めた。 この小論では, これらのいくつかの実験事実をもとに, 吸着単分子膜と不溶性単分子膜の間には明確な境界は存 在しないことを説明した。吸着単分子膜における相転移と不溶性単分子膜の相転移はまったく同じ現象であるこ と, しかし吸着単分子膜の方が不溶性単分子膜よりはるかに平衡に近いこと, 言い方をかえれば, 圧縮される不 溶性単分子膜は非平衡性が高いこと, 不溶性単分子膜のこの非平衡性が, 膜のモルフォロジーあるいはその変化 などに現れること，またこの非平衡性が緩和現象として現れること，等を様々な例を示しながら解説した。

(連絡者：加藤貞二） Vol.49, No.10, 1089 (2000) 